\title{
Mandatory Community Service Program: A Case Study of Young Nepalese Canadians Experiences
}

\author{
Nabin Maharjan ${ }^{1} \&$ Tom O’Neill ${ }^{1}$ \\ ${ }^{1}$ Department of Child and Youth Studies, Brock University, Ontario, Canada \\ Correspondence: Nabin Maharjan, Department of Child and Youth Studies, Brock University, Ontario, Canada. \\ Tel: 1-647-676-4456.
}

Received: July 2, 2018

Accepted: August 5, 2018 Online Published: September 6, 2018

doi:10.5539/jel.v7n6p13

URL: https://doi.org/10.5539/jel.v7n6p13

\begin{abstract}
Canadian schools introduced community service program in 1999 to engage youth in diverse communities of Canada. Many studies have identified the gap in understanding immigrant youths' experience on mandatory community service but has yet to study immigrant youth's experience. Therefore, this paper explores the experiences of young Nepalese Canadians aged 18- 24 who participated in mandatory community involvement for graduating from high schools in Ontario, Canada. The findings are based on qualitative data gathered from ten interviews with young Nepalese Canadians who went to Canadian high schools, and are currently living in the Greater Toronto area (GTA). The study provides a nuanced understanding of visible minority immigrant youth's experiences of mandatory community service in high school. The findings suggest that participants experience the program as merely an obligatory requirement to graduate from high school rather than a platform for learning civic skills and engaging in diverse Canadian communities. In addition, this case study of Nepalese Canadian youth depicts how young Nepalese Canadians depend on informal sources, mainly peer-to-peer sharing, for engaging in community, and illustrates how they conceptualize what community involvement means to them. Finally, based on this study, we argue that amendment to this mandatory program is an urgent call for engaging visible minority immigrant youth civically and meaningfully in Canadian communities.
\end{abstract}

Keywords: Ontario community involvement program, youth civic engagement, youth participation, visible minority immigrant youth

\section{Introduction}

Statistics Canada (2009) report shows that Canada has become a country with the highest proportion of foreign-born population ( 1 in 5 people) among the G8 countries. Although Asia is the major source of immigrants, Nepalese immigrants are a negligible number compared to other Asian countries. However, Nepalese immigration to Canada is growing annually. According to Statistics Canada (2011), 15,220 Nepalese Canadians are living across Canada; and around 12,464 Nepalese migrated to Canada from 2004 to 2014 (Statistics Canada, 2016). Moreover, the latest Canadian census shows that more than one-fifth of Canadians were immigrants-mostly from Asia (61.8\%); and the Province of Ontario remains the key hub for new immigrants. Similarly, many Nepalese-Canadians as well as new Nepalese immigrants (both visible minority ${ }^{1}$ immigrants) live in the most populous metropolitan area of the Greater Toronto Area (GTA).This paper is based on a study of Young Nepalese Canadians living in the Greater Toronto Area (GTA), who have graduated from high school completing 40 hours of mandatory community service as part of the Ontario high school curriculum. We have selected the GTA, which includes Toronto, Mississauga and Brampton, as a suitable research site for this study.

For over two decades, the two main studies on mandatory community engagement, namely Pancer, Brown, Henderson, \& Ellis-Hale (2007) and Meinhard \& Foster (1999), have valued the importance of this program in high schools. Their studies suggest that the Ontario mandatory community services program in high schools has increased youth civic engagement in local communities. At the same time, both studies noted gaps in the implementation of mandatory community service. They found that the community involvement program has been operated without proper support and guidance to young people. The tendency to hasten young people's involvement in community services was identified as a problem for both communities and students (Meinhard \& Foster, 1999, and Pancer, Brown, Henderson, \& Ellis-Hale, 2007). The current practices in high schools' 
applicatino of the community service program, including limited engagement of teachers, school administrations, parents and community centers in the program, is worrisome. This limited involvementof parents, teachers and community centers in the community program suggest that young people have limited guidance to select a community engagement activity that is meaningful. The persistent gap in terms of facilitating young people in the community involvement program results in poor participation of young people (Meinhard \& Foster, 1999; Pancer, Brown, Henderson, \& Ellis-Hale, 2007).

According to Pancer (2015) there are significant gaps in previous studies to understand the impact of early community engagement on visible minority youth. In addition, the general tendency of viewing visible minority groups' experiences as similar too their non-minority groups, has overshadowed the achievement and challenges of visible minority immigrant youth (Pancer, 2015; Molina-Girón, 2018; Gaby, 2017). In this context, studying visible minority (Note 1) immigrant youth's experiences and perspectives on the high school community involvement program is helpful to understanding their community engagement experience, such as that of Nepalese Canadians. It is, therefore, important to understand whether the mandatory community involvement program in Ontario high schools is helping to foster the civic engagement of minority youth. In this paper, we look at how visible minority immigrant youth, especially Nepalese Canadians, perceived and experienced community involvement through the mandatory community involvement program in high schools. Therefore, our focus is to understand their civic participation in Canadian communities at young age, and how their early engagement shaped their perception about civic engagement in Canada.

In academic research, the qualitative approach is considered appropriate to study individual living experiences and interpretations (Creswell \& Poth, 2018). Therefore, we purposively sampled 10 young Nepalese Canadians for this study to obtain key themes from the data by using qualitative data analysis methodology. Our results suggest that most of the visible minority youth especially young Nepalese Canadian perceived the community involvement programs in schools as an obligatory course work. In addition, they felt it as an additional burden as well as a form of exploitation rather than an opportunity to learn civic skills for serving communities in long run.

We have outlined the remaining part in following ways: Literature review section covers the existing literature on civic engagement and youth's involvement in community services. Similarly, methodology section highlights the research process; finding and discussion section provides key results of the study and, finally, followed by conclusion section.

\section{Literature Review}

In this section, firstly, we have explored the roots of the terms "civic" and "engagement" and how the term "civic engagement" is used and conceptualized. Secondly, we have briefly discussed about the importance of youth civic engagement. Finally, we have presented how civic engagement is being introduced and practiced by Canadian high schools, especially in Ontario's "mandatory community involvement program" (Ontario Ministry of Education, 2016).

\subsection{Conceptualizing Civic Engagement}

\subsubsection{Defining Civic Engagement}

Civic engagement is a major concern in the field of youth studies, particularly when studying youth participation in political and public affairs. Numerous scholars have noted and attempted to define civic engagement. To conceptualize civic engagement, it is necessary to understand the root of civic engagement. According to literature on civic engagement, the term "civic" generally refers to citizen or a city, and "engagement" is commonly understood to mean involvement/participation (Ronan, 2011). The literature further suggests that, civic engagement rapidly evolved after the publication of Alex de Tocqueville's remarkable study on American democracy. Tocqueville (1835) uses the idea of "self-initiated public and political associations" to refer to the contemporary concept and the notion of civic engagement.

Further, Putnam (2000) has connected civic engagement with "social capital", referring to a broad concept of civic engagement. He states that social capital means the social connection between people for generating mutual support, cooperation, trust, and the institutional effectiveness of diverse community through collective forms of engagement such as attending meetings, serving on local community clubs and organisations (Putnam, 2000). Therefore, he argues that to sustain the social and political participation of people, we must regenerate the collective value among community people including youth in order to engage civically (Putnam, 2000). Similarly, according to Solomont (2017), democracy can only be strengthened by nurturing the civic life of young people; hence, he emphasized on early engagement of young people in communities. Much of the current 
literature on civic engagement arises from this political science perspective. As a result, most of the earlier civic engagement studies or literatures are associated with political participation, mainly emphasizing electoral voting.

Currently, many eminent scholars from various disciplines, such as Berger (2009) and Henderson, Brown and Pancer (2012), have started to use and define civic engagement beyond the traditional political realm to conceptualize other forms of participation. As a result, civic engagement has been conceptualized in numerous ways from various disciplines (Sherrod, Torney-Purta, \& Flanagan, 2010). According to Berger (2009), diverse disciplinary interpretations lead to confusion because there is no universal definition of civic engagement. For instance, political scientists define civic engagement by focusing on political participation such as electoral voting. Developmental psychologists concentrate on "moral sense development", employing Lawrence Kohlberg's stages of moral development in a person to understand the individual's civic values, attitude and behaviour (Wilkenfeld, Lauckhardt, \& Torney-Purta, 2010). In contrast, educationalists emphasize citizenship education, largely focusing on youth civic responsibilities as a citizen (Torney-Purta, Lehmann, Oswald, \& Schulz, 2001, Pancer, 2015; Putnam, 2000; Sherrod, Torney-Purta, \& Flanagan, 2010; Burger, 2009).

Many scholars such as Burger (2009) and Gaby (2017) highlight this fluidity in the definition of civic engagement. Civic engagement comprises of disciplinary-practised definitions (Adler \& Goggin, 2005), and is often interchangeably associated with "community association", "community participation", "community services" and "community involvement".

Although civic engagement lacks universal definition, Thomas Ehrlich includes key aspects of all disciplinary conceptualizations of civic engagement in his approach (2000). Despite the differences in conceptualization of civic engagement, there are commonalities. All disciplines focus on the participation of individuals in public and private affairs, such as electoral participation, voluntary participation and participation in social movements. Each discipline recognizes the importance of individuals' involvement to develop both individuals and communities. Generally, scholars agree that civic engagement includes political or non-political engagement for serving communities as well as solving community problems individually or collectively (Ehrlich, 2000; Solomont, 2017; Berger, 2009). Although all these nuances of participation are used to understand civic engagement, we will particularly concentrate on voluntary participation/involvement of young people to understand youth civic engagement experiences. Therefore, for this paper, we will use Ehrlich's (2000) definition of civic engagement (especially non-political processes). According to Ehrlich (2000), "civic engagement means working to make a difference in the civic life of our communities and developing the combination of knowledge, skills, values, and motivation to make that difference. It means promoting the quality of life in a community, through both political and non-political processes" (p.vi).

\subsection{Youth Civic Engagement and Its Importance}

Many eminent scholars such as Sander and Putnam (2010), Putnam (2000) and Pancer (2015) assert that youth civic engagement plays a particularly significant role in generating social-wellbeing and social connection of individuals with communities, as well as supporting democratic systems.Adler and Goggin (2005) further elaborated that youth civic engagement not only helps youth to shape their perspectives towards the social and political institutions but also provides choices in terms of participation in the democratic process. In addition, a study on civically engaged youth in community shows that young people will have higher degree of self-esteem and confidence comparing to the non-engaged youth (Pancer, Pratt, Hunsberger, \& Alisat, 2007).

Similarly, a number of studies across Canada and United States focus on the effects of early community involvement programs in high schools. The national survey of giving, volunteering and participating shows that young people are most likely to volunteer in Canada compared to any other aged group (Turcotte, 2015). Similarly, Henderson, Barbara and Pancer (2012) assert that the number of youth volunteers in universities has increased due to their positive experience in high schools. In the same vein, Ain (2003) notes that the institutionalized community involvement program in US high schools has played an important role in youth volunteerism growth. Many scholars agree that introducing community engagement programs in high schools helps young people to have a meaningful experience of community involvement and creates a lasting impact on youth to volunteer in their communities (Ain, 2003; Meinhard\& Foster, 1999; Pancer, 2015; Pancer, Brown et al., 2007; Sherrod, Torney-Purta, \& Flanagan, 2010).

To date there has been a general assumption that all young people engaged in community services, including visible minority youth, will have similar experiences. Most of the contemporary studies such as Pancer et al. (2007) on youth community engagement have failed to consider the socio-cultural and class differences in terms of individuals' community involvement experience. The generalisation of youth experience, without considering visible minority youth's experience is problematic (Sanchez-Jankowski, 2002; Gaby, 2017). Realizing the 
importance of bringing forward visible minority immigrant youths' perspectives and experience on civic engagement, our study is focused on young Nepalese Canadians' engagement in 40 hours community involvement program of Ontario High schools.

\subsection{Compulsory Community Involvement Programs}

As noted above, most policy makers, educators and scholars (Flanagan \& Levine, 2010; McFarland \& Thomas, 2006; Solomont, 2017) have found that the compulsory engagement of young people in community services has increased the participation of young people in community activities. They emphasize that early civic engagement helps young people to learn civic goals and become responsible citizens in democratic society. Therefore, many developed countries including Canada, with an aim of reversing the declining youth engagement in formal political and public affairs, have introduced civic engagement programs in high schools as their pedagogical goal (Torney-Purta et al., 2001; Padanyi et al., 2009; Pancer, Brown, Henderson, \& Ellis-Hale, 2007).

In addition, Padanyi et al. (2009) state that madatory high school community service has provided a space for volunteers to engage in community; and the early engagement platform certainly helps youth in terms of their longterm engagement in community. A study on Ontario's high school community service programfound that many young people who are actively engaged in high schools beyond the requirement are still participating in community service (Padanyi et al., 2009). Furthermore, Almond and Verba (1989) and Solomont (2017) highlight the importance of social institutions such as schools for fostering youth's participation in community affairs as well as for teaching civic skills to strengthen the democratic practices. According to Verba, Schlozman, and Brady (1995), civic skills refers to the individual's capacity to participate especially in political affairs, which can be taught in the early days of adolescence.

In Canada, most of the provincial governments have introduced community engagement programs in high schools (Sagan, 2015). Each province has a particular program or policy to engage high school students in community. In 1999, Ontario - one of ten provinces - introduced mandatory 40 hours community service in every high school for greater involvement of youth in Canadian communities (Sagan, 2015). One of the major goals of this program is to develop an awareness and understanding of civic responsibility so that young people can support and strengthen the local communities (MoE, 2016). Each student needs to accumulate 40-hour community services within 4 years from grade 9-12 in order to graduate from high school (MoE, 2016).

Although mandatory community involvement programs have been implemented for around 20 years in Canadian high schools, the program policy and procedures appear to be unchanged from its initation days. The numerous studies on the impact of 40 hours of community services on young people have consistently recommended changes in the community involvement program for meaningful engagement of students (Meinhard \& Foster, 1999; Henderson, Brown, \& Pancer, 2012). Although mandatory community involvement program has various benefits to youth, the level of impact on individuals depends on two features, mainly individual commitment and placement experience (Pancer et al., 2007). Visible minority youth's commitment and experience might be far different from the non-minority youth; as a result, the impact of mandatory engagement will definitely varies in this context.

As noted above, contemporary research on mandatory community involvement programs has failed to include the experience of visible minority immigrant youth's involvement in community services. Although the Canadian government promotes inclusivity in Canadian schools, many scholars such as Dei (2008) and Gosine and Islam (2014) are still sceptical about the fairness of treatment to minority students in the schools. Dei (2008) argues that differential treatment persists in Canadian high schools. Though most of the minority immigrant groups such as black, South Asian and Chinese communities possess several common challenges related to socio-economic factors, a range of differences exist across visible minority immigrants such as culture, class and education. These differences in terms of culture, gender and race contribute to differential participation experiences (Gaby, 2017; Pancer 2015). In this context, it is interesting and important to explore how the community involvement program in high schools is contributing to young Nepalese Canadian's specific engagement in community service. In civic engagement studies, considering the participation process and experiential differences of visible minority groups during community involvement could be helpful to illustrate existing disparities between immigrants and non-immigrants in community involvement as Pancer, (2015) and Gaby (2017) stated in their studies. In addition, Nepalese Canadian's are newly emerging immigrants in Canada and it will be interesting to understand how these young people are engaging in Canadian communities through the mandatory community services. Therefore, this paper will explore young Nepalese Canadian's participation contexts and interactions with parents, school administration and community organisations during their community services in high school. 


\section{Methodology}

We used the social constructionist perspective to understand the young people's experience of community service, particularly focusing on their voluntarily participation. In other words, we sought an understanding of youth people's thoughts, values, perspectives, and definitions of the mandatory community services program. Although, to some extent the compulsory community service program also envisions participation of youth in formal politics in the long run, most school board listed activities are presently focused on social and community activities, therefore, this study focused only on the voluntarily aspects of civic engagement. For this study, we employed a qualitative approach to explore Nepalese Canadian youths' experiences engaging in communities as a single instrumental case (Creswell \& Poth, 2018).

According to Stake (1995), an instrumental case study helps us to have in-depth understanding of issues or problems related to particular case. In addition, Yin (2011) states that case study is widely used to understand in detail the phenomena of a particular group to see the context and processes in that particular case. The goal of this study was to explore how youth are experiencing this mandatory volunteering program, and why young Nepalese Canadians are perceiving and experiencing the program in different ways from other young people (Creswell \& Poth, 2018). Therefore, this study employed a case study method to explore the experience of ten young Nepalese Canadian aged 18 to 24 for understanding how these young people are perceiving and experiencing the mandatory community services program; and why young people are engaging in particular kinds of community services for the mandatory program.

The interview data were collected from 10 young people (6 females and 4 males) who were living in Greater Toronto Area (GTA) and had completed 40 hours community services in high school. The sample was purposively selected to incorporate a diversity of Nepalese Canadians in terms of ethnicity, class and gender. An invitation poster was placed in key sites where Nepalese Diaspora frequently visited, namely Nepalese immigrant-led community organizations working in the GTA, temples and Non-Residential Nepalese Association (NRNA). The participants who responded to the advertisement with interest were contacted. Later, each participant was interviewed in a convenient place for them, mostly at home or at the public library. A consent form was collected before starting the interview. In the data collection process, face-to-face, semi-structured, in-depth interviews were completed with an open-ended questionnaire (Yin, 2011), and each interview was audio-taped with consent. Once the data were collected, recorded interviews were transcribed. Later on, transcribed data were reviewed to find the specific key words of each case. As Yin (2014) suggests, a word table of individual data was created which displays the information of individual cases and helps to synthesis the data for exploring similarities and differences in the analysis process. The synthesized information was compared and analyzed to explore uniform patterns from the data set and used in our research findings.

\section{Findings and Discussion}

By analyzing interview data, and comparing the emerging concepts with the policy documents, the following sets of themes/categories emerged 1) visible minority youth's learning experience and outcomes mainly involvement as a means to graduate, engagement as a memes and involvement as a punishment; and 2) community experience differences among visible minority youth mainly in terms of gender and class.

\subsection{Visible Minority Youth's Learning and Outcomes}

\subsubsection{Community Involvement: A Means to Graduate, Not to Learn Civic Skills}

The official document "The Ontario Schools Kindergarten to grade 12, Policy and Program Requirement (2016)"explicitly states that the community involvement program is envisioned to develop civic skills among young people so that they are able to contribute in their respective communities and to solve community problems (Ontario Ministry of Education, 2016). Our data suggests that the obligatory provision that students must complete this service in order to graduate from high school has constructed the program as a degree-driven process rather than learning-driven engagement. As a result, most of the students we interviewed primarily concentrated on accumulating 40 hours community services as soon as possible. For example, Ruby said that

I came to know about it (40 hours) through my cousin, who was here (in Canada) before us. She came one year before me. She told [me] that she needs to complete the 40 hours in order to graduate high school. That's the reason, I started volunteering by grade 8 .

Similarly, a few respondents shared that they were persuaded to focus on accumulating hours to graduate rather than focus directing on meaningful participation. For example, Rishan shared that "I had friends whose graduation was delayed because they did not fulfill community hours". Furthermore, Roji added that the primary discussion among peer groups is about accumulating hours to graduate - " 40 hours was my first priority because 
you need it to graduate. Everyone I knew told me that you had to do it early because you don't want to keep it for the last minute".

Often, peer groups who accomplished community engagement in high schools informally share information about the early accumulation and timely completion of 40 hours. Therefore, most respondents started their community involvement at grade 10. Although these young people were actively engaged in doing their community service, they perceived this program to be a means to graduate from high schools and focused on completion rather than learning civic skills. This focus on graduation contradicts the goal of the mandatory community involvement program.

Except in few cases, school administrators and teachers failed to share sufficient information about the mandatory community involvement program, especially in terms of guidance. This shows that information dissemination from schools on this program is inadequate to fulfil students' desire about what kind of civic engagement they should do. The traditional way of instruction, which involved continuous warnings to students about the possibility of failure to graduate due to the lack of 40 hours community services, further fuelled students to focus only on accumulating their40 hours. One respondent, Sabina, shared how her teachers informed her class about the program, which led her to focus on collecting hours when she was in grade 8: “.... Oh guys make sure you complete your 40 hours or else you don't graduate' (said by teachers to students)...that was the only motivation we got". This way of disseminating information about the community involvement program means school personnel are perfunctory in running the program, rather than fostering students' quality community engagement. Pancer, Rose-Krasnor and Loiselle, (2002) and Meinhard \& Foster, (1999) express much the same point, claiming that the school system plays a vital role in creating meaningful experience of youth engagement if they put some extra effort.

\subsubsection{Community Engagement: More Like a Meme than Engaging}

In the process of learning about the community involvement program, many participants shared that schools provide brief information about the program. It was found that most youth are not well informed about the goals of community involvement program, except it is a prerequisite for graduating from high school. Since the program is associated with graduating from high schools, most family siblings or elders (informal sources) continuously reminded students about accumulating 40 hours, which ultimately diverts the meaningful engagement of visible minority youth in communities. Only few respondents sought to gather information about community services from official sources such as guidance counsellors, as explained by Rishan:

"Basically, you go to the guidance counsellor if you need help, whether it be academic or personal or whatever kinda problem you have, you go to them and they give you a bunch of resources that you can do and they give you options as to what can you follow. So yeah, guidance counsellors help a lot."

Rishan, however, was an exception among our participants. In the process of gathering information and connecting with community organisations, most students use various ways to find placements, such self-initiating, receiving help from former or current peers, teachers, or guidance counsellors, and getting support from family members (Pancer, Brown, Henderson, \& Ellis-hale, 2007). However, in this study, as mentioned above, non-minority youth largely relied on their own peer circle (friends and elders) rather than teachers and guidance counsellors, which ultimately made community involvement more like a meme than engaging. For instance, Rabina shared,

“Like I said they (school) didn't know about my struggle. I was struggling to find a community centre, but I was not able to express. I was too shy to go to any school counsellor and talk about anything. I never really approached to them (school) except for courses. That's it. They (Teachers) never called me to talk about my school. I was more comfortable to ask my friends than the guidance counsellor...... I always asked my friends. I made some really good friends."

The limited academic and social support for accessing information related to school program placed minority youth in vulnerable situations in high school. Inadequate information from formal sources further placed them at risk of not achieving their community involvement goals. Roji's experience demonstrated that students could be misled or even disengaged from community involvement due to relying on informal sources entirely.

"At the beginning, I chose Ram Mandir (a Hindu temple where devotees largely volunteer for daily rituals and services) because I didn't know where else to go. When my friends told me that when you go to the Mandir you get hours that was my first choice. But then after I realized even though I am volunteering I should at least gain some experience in my own field, like Zonta (a local high school's club that organizes 
fundraising activities and other social events for supporting victims of natural disaster), where you get to work closely with professors or college students. Sometimes they come in to present.

The limited practices to access information about community involvement program within schools and higher dependency on informal sources for gathering information suggested that minority youth were unable not only to receive proper information but also unable to engage meaningfully in their civic involvement. This lack of guidance ultimately limited visible minority youth's civic learning as well as their engagement in wider community. As Ballard (2014) signifies, here we see the "systemic barriers" for meaningful engagement of young people.

\subsubsection{Community Engagement-Reward or Punishment?}

According to Berger (2009), engagement comprises both activity (an investment of energy) and attention (a consciousness of purpose). In the policy document for the community involvement program, it explicitly states that schools should be attentive towards providing a list of potential community activities as well as engaging students in meaningful learning (Ministry of Education, 2016). Schools' proactive role certainly helps to foster a sense of engagement -literally making youth invest their time/energy purposefully. However, in the study findings here, a consciousness of the purpose for their community engagement (other than graduating from high school) was either missing or side-tracked. However, one respondent shared her experience of community engagement as rewarding and felt a sense of satisfaction and accomplishment. Rabina said:

When I was volunteering, I was really happy that I was doing something for the community.... I did get to meet new people, made friends, they were all nice.

In contrast, most of the participants who were involved in community activities without any purpose, experienced the community engagement as a punishment, as Nilesh shared:

I don't have enough time now. There is also no motivation to do so. There are no obligations. Why do I

have to do this? It is a total waste of my time. Why am I doing 40 hours, if I am not getting paid for it?

Similarly, Roji elucidated that "Ram Mandir (a Hindu temple) was just a terrible experience. I don't think I will ever go back. They (temple staff) asked me wash dishes and it was not even small dishes. They were big dishes and really heavy for one person to handle.... They were never satisfied. They would just keep adding our hours."

Few Nepalese-Canadians found engagement in community as a reward; rather the majority of youth considered community engagement as punishment and confirmed that the purpose of their participation is only to graduating from high school - an ultimate reward.

\subsubsection{Community Involvement Program: An Opportunity to Connect Early}

Most community engagement programs anticipate connecting youth with local communities at an early age. Many scholars believe that the early engagement of youth in community strengthens the community as well as fostering individual responsibility towards community (Pancer, 2015; Putnam, 1996; Solomont, 2017).However, only few young people in this study who were engaged meaningfully at an early age were able to connect well with local communities. For example, Ruja who volunteered at early childhood center with the help of school indicated that

It (community involvement) just means, sparing some of your time that you don't just sit at home and do nothing. You can help out people who need help.

Similarly, Roji said that "I think you learn about what's available in the community and also what is the need of the community." Those who were able to connect well with community during their placement could recognize the value of community engagement. Most Nepalese Canadians youth engagements at the early age were unable to connect with community. A study found that students who have meaningful experiences in community at early age were able to make career orientation decisions properly (Pancer, 2010). However, most Nepalese Canadian youth were neither able to connect their civic engagement with community, nor to their personnel interest/career. For instant, Suraj shared that 'I was just like giving out food. Doing dishes. It didn't add any value to me. It was giving back, it was a temple, but I should have done something that would have benefited me as well. So yeah... that's why I was not very satisfied."Such evidence supports Ballard's (2014) argument that creating an opportunity for youth to engage in community will not be enough if it does not connect with the youth's interest and passion.

\subsection{Community Engagement: Differences Within Visible Minority}

According to Ballard's (2014) study on youth civic involvement containing both highly active non-active youth within and across school context for community services, it was found that youth civic involvement largely 
depends on the individual's socio-cultural, economic status and gender. Although selection of community activities depend largely on students' own choices (Ministry of Education, 2016), individual social context plays an important role in experiencing community services (Ballard, 2014). As a result, community involvement programs offer each individual a different experience, based on their gender, race and class identities.

\subsubsection{Gender}

Since women are socially constructed as care-takers and nurturers (Wilson \& Musick, 1997), community service, especially volunteer work, is largely gendered. For example, in many countries including Nepal, most of the community health volunteers are female (Glenton, 2010). Therefore, most of the girls in our study still felt that community care is a primary duty of their life even after the completion of high school, as Ruby stated:

I really enjoy working with children and getting involved in the community. I had 1900 hours by the end of my high-school. ...If I get a chance, I will definitely continue (involving in community)...Like my brother he takes it as an assignment rather than contributing to society. He just did 40 hours and did not go beyond it.

Similarly, Rabina shared that

Right now I volunteer with Canadian Blood services. I received the training and everything. [...] I also volunteer with Red Frogs. It is a local church....I also recently finished my training with the Alzheimer's society, so I should be starting with them soon as well.

The experiences of girls in this study, which are congruent with the Statistics Canada 2016 data on volunteerism, reflect that volunteer work is largely associated with females. Although, mandatory involvement has reduced gender inequality in civic participation (Turcotte, 2015), the activities are still gendered; and women's gender-specific activities are unchanged compare to men. Most of the girls in this study chose to volunteer at a pet store, childcare center or in temples, whereas most of the boys worked doing administration or teaching swimming in community centers such as the Young Men's Christian Association, (YMCA). The specific work the girls did was also often gendered in terms of care-giving. For example, one of the female participants (Roji) shared that

In Mandir (a Hindu temple), I learnt that work is very gender specific. Men were doing one thing and women were all in the kitchen. I found that really interesting. They (men) were "not" doing things that we could not do. They were just fixing tables in the dining room...

Although both boys and girls are involving in community services, both are looking for future opportunities which are more gendered specific such as girls considering care-based programming while boys are looking for paid related work for civic engagement. Rishan (male participant) shared this link between placement choices and future goals.

For high-school kids, community service is the first opportunity to know about the workforce. I am not talking about everyone, but for most of the students. They have not had job prior to the volunteer experience, so volunteering is their first exposure to that world. Definitely learn skills.

These subtle gender differences in experiencing the community activities were found among the participants. Their variation in choices and experiences is a useful reminder that longer term prospective around unpaid or underpaid work for women still exist in subtle way and gender-based discrimination still prevails in terms of engaging in community.

\subsubsection{Ethnic Minority: Class Struggle and Exploitation}

According to Albanese (2009), most minority immigrant parents are largely inspired by the higher education for their children. In addition, a study by O'Neill et al. (2017) showed that most Nepalese-Canadian immigrant parents have high levels of academic qualification, but are still working precarious jobs in Canada to sustain a livelihood. Poor living standards of Nepalese-Canadian (minority) compared to non-Nepalese Canadian often leads to a lack time for involvement with their children. In this context, most of the parents are unable to engage in and support their child's school activities (Yesufu, 2013; Pancer, 2015). Although, Putnam (2000) argues that parents' higher education increases the possibility of civic participation; this does not necessarily apply to visible minority families and their kids. Most of the participants shared that their parents are neither well-informed about the mandatory community involvement program, nor actively involved in the process to facilitate their children in community engagement. Ballard (2014) found that 'systemic barriers'-lack of opportunity, time, resources, experience, knowledge and power-hinder not only students but also parents' civic participation in the community. This is the case in Nepalese Canadian communities. 
Most youth shared that their parents know only about the requirement of the 40 hours community services for high school graduation. Thus, parents simply ask their children to complete their volunteer hours and barely assist in their children's involvement in community organizations or to cope with new community environments. As Suraj explained that 'they (parents) didn't give me assistant but they just asked to me get it done as soon as possible. Make sure you graduate'. Therefore, many authors argue for the necessity of "adult supportiveness" to young people, especially among marginalized groups, for their greater and meaningful engagement in communities (Meinhard \& Foster 1999; Pancer, 2015).

The study also found that most participants from working classes felt that they were wasting their time and energy, and did not learn any civic skills from their involvement in community, as Sabina stated:

Not unless my mom forces me to!... I would rather get paid for my work. If you (are a) volunteer, you are wasting your time and time is money. Like as you get older... I am going into college, now I gotta pay tuition. I have to also work and provide.

Youth's perspectives on volunteer hours, mainly comparing volunteer work with monetary value, depict the challenges facing visible minority ethnic youth and their parents' economic inability to support their children for engagement in community. Therefore, young people from working class have limited luxury to do volunteering at their own community even though they are interested to contribute. Gaby (2017) and Pancer, Brown, Henderson, \& Ellis-Hale (2007) make similar points about the impact ofsocio-economic status in community involvement activities. For instance, Pancer (2015) claims that "when individuals (poor, minorities, immigrants, youth) feel they have no power and no influence, they are less likely to become civically and politically engaged" (p178).Therefore, the experience of minority youth in community involvement contributed to the perception that community service is a painful process and just necessary for graduating from high school. In addition, the limited guidance, support as well as supervision from parents, school and community organisations during community service further solidified their experience. As Ballard (2014) suggests, there should be an effort to connect the youth's interest and passions during the civic engagement process rather than just creating a space for volunteering in the community.

Apart from class struggle, many participants often experienced exploitation and were unfair treated by community organisations, yet there was no space for them to talk about their negative experiences. Since the government policy states that students are "responsible for fulfilling their community involvement requirement on their own" (MoE, 2016), participants felt that all consequences were the result of their own choices. As a result, most participants' minority youth blamed themselves, even though they felt that they were exploited by the community organisations, as Roji shared

....(working in) a temple was just a terrible experience. I don't think I will ever go back. They asked me wash dishes and it was not even small dishes. They were big dishes and really heavy for one person to handle. I kinda saw things there. They were not handling food properly. They would not wash utensils properly, so I would not suggest people eating there. They didn't treat us nicely. They were never satisfied. They would just keep adding our hours. Like, if I was supposed to be there for 2 hours, they would make you stay. Sometimes people call in sick or they are late, you have work on their behalf even through you are not trained to do that.

Such instances of exploitation are not reserved for visible minority youth, although visible minority youth may have fewer resources to challenge it. These experiences in the early days of community engagement certainly demotivate youth, especially visible ethnic minority to be involved in community in the long run. Certain motivation, preventive measures and incentives are necessary from all sectors including parents, schools and community organisation to engage youth in community.

\section{Conclusion: "A Little Impetus"}

The integration of Ontario's community involvement program in 1999 in the official policy document -"Ontario Schools Kindergarten to grade 12, Policy and Program Requirement" was intended to develop civic skills and responsibilities among young people including minority youth in high schools (MoE, 2016). The vision of developing civically engaged youth at the early age through this program has failed to ignite minority youth for involving in Canadian communities due to limited changes in its intervention modalities, and the program remains burdensome to many visible minority youths. Most of the students perceived the community involvement program as an obligatory course work rather than an opportunity to learn civic skills, and some even struggled and felt exploited. 
On the one hand, multiple options within the program for choosing community activities allow students to have freedom in selecting local community organisations that work best for them. On the other hand, these choices, without substantial guidance, lead to ambiguity in community engagement and ultimately construct a distorted view of civic engagement and instead foster the long-term disengagement of visible minority youth. If the key goals of the community involvement program were well-defined, properly processed, and regularly supervised, with more guidance for students, then it could ensure the meaningful engagement of visible minority youth with the possibility of eliminating or reducing volunteer exploitation and gender discrimination. One important outcome of this study is that school administration, including teachers and guidance counsellors, and parents need to rethink their engagement in the community involvement program to ensure the meaningful participation of visible minority immigrant youth particularly in multicultural communities without any form of labour exploitation, class, ethnic and gender discrimination. However, due to time limits, the study does not include other categories of civic engagement such as participation in electoral politics and in social movements and largely focused on social engagement. Further studies on visible minority youth's integrating both political and apolitical participations help to understanding their diverse experiences of engagement in multicultural Canadian communities.

\section{References}

Adler, R. P., \& Goggin, J. (2005). What do we mean by civic engagement? Journal of Transformative Education, 236-253. https://doi.org/10.1177/1541344605276792

Albanese, P. (2009). Ethnicity, Immigration and Family Life. In M. Baker \& P. Albanese (Eds.), Families: changing trends in Canada (6th ed., pp. 130-153). Toronto: McGraw-Hill Ryerson.

Almond, G. A., \& Verba, S. (1989). The civic culture revisited. Newbury Park, CA: Sage Publication.

Ballard, P. J. (2014). What motivates youth civic involvement? Journal of Adolescent Research, 29(4), 439-463. https://doi.org/10.1177/0743558413520224

Berger, B. (2009). Political theory, political science, and the end of civic engagement. Perspective of Politics, 7(2), 335-350. https://doi.org/10.1017/S153759270909080X

City for All Women Initiative (CAWI) and City of Ottawa. (2017). Equity and Inclusion Lens Guide and Snapshots. Ottawa: Status of Women Canada and the City of Ottawa.

Creswell, J. W., \& Poth, C. N. (2018). Qualitative inquiry and research design: Choosing among five approaches (4th ed.). Thousand Oaks, California: Sage.

Dei, G. J. (2008). Schooling as Community Race, Schooling, and the Education of African Youth. Journal of Black Studies, 38(3), 346-366. https://doi.org/10.1177/0021934707306570

Ehrlich, T. (2000). Civic responsibility and Higher education American Council on Education. Westport, CT: Greenwood Publishing Group.

Flanagan, C., \& Levine, P. (2010). Civic engagement and the transition to adulthood. The Future of Children, 20(1), 159-179. https://doi.org/10.1353/foc. 0.0043

Gaby, S. (2017). The Civic Engagement Gap(s): Youth Participation and Inequality from 1976 to 2009. Youth and Society, 49(7), 923-946. https://doi.org/10.1177/0044118X16678155

Glenton, C., Scheel, I. B., Pradhan, S., Lewin, S., Hodgins, S., \& Shrestha, V. (2010). The female community health volunteer programme in Nepal: Decision makers' perceptions of volunteerism, payment and other incentives. Social Science and Medicine, 1920-1927. https://doi.org/10.1016/j.socscimed.2010.02.034

Gosine, K., \& Islam, F. (2014). It's Like We're One Big Family: Marginalized Young people, community and the implication for Urban Schooling. School Community Journal, 24(2), 33-62. Retrived from https://files.eric.ed.gov/fulltext/EJ1048618.pdf

Henderson, A., Brown, S. D., \& Pancer, S. M. (2012). Political and Social Dimensions of Civic Engagement: The impact of Compulsory Community Service. Politics \& Policy, 40(1), 93-130. https://doi-org.proxy.library.brocku.ca/10.1111/j.1747-1346.2011.00341.x

McFarland, D. A., \& Thomas, R. J. (2006). Bowling young: How youth voluntary. Americal Sociological review, 401-425. https://doi.org/10.1177/000312240607100303

Meinhard, A., \& Foster, M. (1999). The Impact of Volunteer Community Service Programs on Students in Toronto's Secondary Schools. Toronto: Ryerson Polytechnic University. Retrived from http://www.ryerson.ca/content/dam/cvss/reports/1999\%20v1\%20The\%20impact.pdf 
Ministry of Education (MoE). (2016). Ontario Schools, Kindergarten to grade 12 Policy and Program requirements. Ontario: Service Ontario. Retrived from http://www.edu.gov.on.ca/eng/document/policy/os/onschools_2016e.pdf

Molina-Girón, A. L. (2018). The civic and political engagement of Canadian Youth. In X. Chen, R. Raby, \& P. Albanese (Eds.), The sociology of Childhood and Youth in Canada (pp. 378-394). Toronto: Canadian Scholars Press.

Olson, G. A., \& Worsham, L. (2012). Education as civic engagement. New York: Palgrave Macmillan. https://doi.org/10.1057/9781137021052

O’Neill, T., Makaju, U., Shrestha, R., Shrestha, B. M., Sthapit, Birendra, R. S., \& Tamrakar, N. (2017). The Nepali-Canadian Living Standards Survey: Newcomer incorporating in the Greater Toronto Area. Unpublished Manuscript.

Ontario Ministry of Education (OMoE). (2016). Ontario Secondary Schools, Grades 9 to 12 Program and Diploma Requirement 2016. Toronto, Canada: Ministry of Education. Retrived from http://www.ontla.on.ca/library/repository/mon/7000/10279055.pdf

Padanyi, P., Baetz, M., Brown, S. D., \& Henderson, A. (2009). Does required volunteering work? Results from Ontario's High School Community service program. (Fact Sheet). Toronto: Southern Ontario Social Economy Research Alliance. Retrived from http://sec.oise.utoronto.ca/english/pdfs/factsheets/factsheet23F.pdf

Pancer, S. M. (2015). The Psychology of Citizenship and Civic Engagement. Toronto: Oxford University Press. https://doi.org/10.1093/acprof:oso/9780199752126.001.0001

Pancer, S. M., Brown, S. D., Henderson, A., \& Ellis-Hale, K. (2007). The impact of high school Mandatory Community Service Programs on Subsequent volunteering and civic engagement. Toronto: Knowledge Development Centre, Imagine Canada.

Pancer, S., Pratt, M., Hunsberger, B., \& Alisat, S. (2007). Community and political involvement in adolescence: what distinguishes the activists from the uninvolved? Journal of Community Psychology, 35(6), 741-759. https://doi.org/10.1002/jcop.20176

Pancer, S., Rose-Krasnor, L., \& Loiselle, L. (2002). Youth Conferences as a context for engagement. New Directions for Youth Development, 96, 47-64. Retrived from https://doi.org/10.1002/yd.26

Putnam, R. D. (2000). Bowling Alone: The collapse and revival of American Community. Toronto: Simon and Schuster Paperbacks. https://doi.org/10.1145/358916.361990

Putnam, R. (1996). The decline of civil society: how come? so what? Ottawa: Canadian Centre for Management Development.

Ronan, B. (2011). The Civic Spectrum. Ohio, US: The Kettering Foundation.

Sanchez-Jankowski, M. (2002). Minority Youth and Civic Engagement: The impact of group relations. Applied Developmental Science, 6(4), 237-245. https://doi.org/10.1207/S1532480XADS0604_11

Sander, T. H., \& Putnam, R. D. (2010). Still Bowling Alone? The post -9/11 split. Journal of Democracy, 21(1), 9-16. https://doi.org/10.1353/jod.0.0153

Sherrod, L. R., Torney-Purta, J., \& Flanagan, C. (2010). Handbook of Research on Civic Engagement in Youth. New Jersey: John WIley and Sons, Inc. https://doi.org/10.1002/9780470767603

Stake, R. (1995). The art of case study research. Thousand Oaks: Sage Publication.

Statistics Canada. (2011). National Household Survey. Ottawa: Statistic Canada Catalogue No. 99-010-x2011028.

Statistics Canada. (2016). Permanent and temporary immigration to Canada from 2012 to 2014. Ottawa: Statistics Canada Catalogue no. 91-209-X. Retrived from https://www150.statcan.gc.ca/n1/en/pub/91-209-x/2016001/article/14615-eng.pdf?st=9TSKbuas

Tocqueville, A. (1835). Democracy in America. (E. George Lawrence Trans: JPMayer, Trans.) New York: Perennial Classics.

Torney-Purta, J., Lehmann, R., Oswald, H., \& Schulz, W. (2001). Citizenship and Education in Twenty-eight countries. Amsterdam, The Netherlands: The International Association for the Evaluation of Education Achievement. 
Turcotte, M. (2015). Volunteering and Charitable giving in Canada. Ministry of Industry. Ottawa: Statistics Canada. Retrieved from https://www150.statcan.gc.ca/n1/en/pub/89-652-x/89-652-x2015001-eng.pdf?st=2m1C4LOQ

Wilkenfeld, B., Lauckhardt, J., \& Torney-Purta, J. (2010). The relation between developmental theory and measures of civic engagement in research on adolescents. In L. R. Sherrod, J. Torney-Purta, \& C. A. Flanagan (Eds.), Handbook of Research on Civic Engagement in Youth (pp. 193-220). New Jersey: John Wiley and Sons, Inc. https://doi.org/10.1002/9780470767603.ch8

Wilson, J., \& Musick, M. (1997). Who Cares? Toward an integrated theory of volunteer work. American Sociological Review, 62, 649-713. https://doi.org/10.2307/2657355

Yesufu, A. (2013). Challenges of the visible minority families:Cultural sensitivity to the rescue. Canadian Journal of Family and Youth, 5(1), 107-149. Retrived from http://ejournals.library.ualberta.ca/index/php/cjfy

Yin, R. K. (2011). Applications of case study research (3rd ed.). Thousand Oaks: Sage Publication.

Yin, R. K. (2014). Case study research:Design and method (5th ed.). Thousand Oaks: Sage Publication.

Ain, S. (2003, March 23). The Logic of Mandatory Volunteerism. New York, New York, USA: The New York Times.

Sagan, A. (2015, October 1). High school volunteering: As some struggle to secure hours, other raise bar. $C B C$ News. Toronto, ON, Canada: CBC News.

Solomont, A. D. (2017, April 19). What's your Civic Life? Why does it matter. Retrieved from https://www.huffingtonpost.com/amb-\%20alan-d-solomont/whats-your-civic-life-why_b_9695782.html

Statistic Canada. (2017, Oct 25). Immigration and ethnocultural diversity: Key results from the 2016 Census. Retrieved from http://www.statcan.gc.ca/daily-quotidien/171025/dq171025b-eng.htm

\section{Note}

Note 1. According to Statistics Canada (2015). "Visible minority" refers to "persons, other than Aboriginal peoples, who are non-Caucasian in race or non-white in colour". Whereas the terms "racialized minority" or "people of colour" are used to recognize the historical and contemporary racial prejudice of society towards an individual and beyond individuals to groups/communities. (CAWI and City of Ottawa, 2017). Although, there is a subtle difference in using "visible minority" in comparison to "racialized minority" or "people of colour", these terminologies represent people who are coming from various countries to live in, different in skin tone (non-white), culture, language, and power relations. Since the Canadian Government officially use "visible minority" to define immigrant diasporas, therefore, we also used it to define immigrant populations for this paper.

\section{Copyrights}

Copyright for this article is retained by the author, with first publication rights granted to the journal.

This is an open-access article distributed under the terms and conditions of the Creative Commons Attribution license (http://creativecommons.org/licenses/by/4.0/). 